\title{
Vegetation development in sown field margins and on adjacent ditch banks
}

\author{
Jinze Noordijk • C. J. M. Musters • \\ Jerry van Dijk • Geert R. de Snoo
}

Received: 16 April 2009/Accepted: 29 June 2010/Published online: 11 July 2010

(C) The Author(s) 2010. This article is published with open access at Springerlink.com

\begin{abstract}
The creation of temporal and newly sown field margins for 6 years is a common agri-environment scheme (AES) in the Netherlands. Conservation profits resulting from AES vary over different areas and need further studying. We examined plant species richness in such field margins and adjacent ditch banks in the province of Zeeland, where these linear elements do not experience plant biomass removal after mowing as management strategy. First, during 2 years, we inventoried field margins sown with a wildflower mixture and related the species composition and richness to the age of the margins. In a second assessment, we studied plant species richness on ditch banks protected from arable fields by these margins. Major clusters in a principal component analysis (PCA) on species composition in the field margins showed a succession from sown and ruderal annual species (year 1), to sown perennial species (year 2) and ending with a dominance by tussock forming grass species and Urtica dioica (year 5-6). Total plant species richness decreased with increasing age of the margins, and this was caused by the combination of a decline in sown species and a stable number of not-sown species. The presence of field margins during several years did not result in an
\end{abstract}

J. Noordijk · C. J. M. Musters ( $₫)$ · J. van Dijk ·

G. R. de Snoo

Institute of Environmental Sciences, Leiden University, P.O. Box 9518, 2300 RA Leiden, The Netherlands

e-mail: musters@cml.leidenuniv.nl increase in plant species richness on adjacent ditch banks. In both the field margins and on the ditch banks, mowing management is not followed by the removal of the cuttings. For plant conservation, the results of these field margins are disappointing, probably due to the lack of a proper management. Therefore, we recommend implementing a haymaking and opening management, to increase plant richness and to reduce noxious weeds in the margins and on the ditch banks.

Keywords Agri-environment scheme (AES) · Plant species richness - Succession .

Weeds

\section{Introduction}

Agri-environment schemes (AES) are increasingly used in agricultural landscapes, with primary aims to enhance biodiversity and to maintain or promote attractive or historic landscapes (e.g., Whittingham 2007). Implementation of these schemes is subsidised with public money, from regional, national or European funds. Since AES might not always be effective in reaching conservation goals (Kleijn and Sutherland 2003; Kleijn et al. 2006; Blomqvist et al. 2009), evaluation should be an important aspect to confirm the value or to propose improvements of the management involved. A common AES is the 
creation and management of all types of semi-natural vegetation. Frequently established semi-natural areas on arable lands are field margin habitats (e.g., de Snoo 1999). These margins can have a range of nature conservation functions, including the provision of wildlife habitat, refuges and corridors (e.g., Asteraki et al. 2004; Walker et al. 2007). In addition, these margins may provide other useful functions, such as the reduction of manure and pesticide drift into adjacent ditches (de Snoo and de Wit 1998; Marshall and Moonen 2002).

The creation of field margins is a widely applied AES in the Netherlands (Manhoudt and de Snoo 2003). In this article, we focus on the margins created in the most south-western part of this country: the Province of Zeeland. Although the primary goal of these particular margins is to provide habitat for animals, the composition of the vegetation is regarded as highly important. First, because the vegetation composition determines to a large extend the animal composition (Schaffers et al. 2008). Second, plant species richness has decreased dramatically in agricultural landscapes, and field margins are expected to act as refuges for plant species richness (Kiss et al. 1997; Moonen and Marshall 2001). Third, some plant species are unfavourable to farmers, as seeds or roots easily intrude the arable fields (de Cauwer et al. 2008; Musters et al. 2009). And finally, plant species composition determines the general appearance of the margins, which holds importance to public opinion and acceptance by farmers of these margins (Marshall and Moonen 2002).

The first goal of this study was to gain insight in vegetation development of newly sown field margins under a widely applied AES which prescribes that these elements have to be maintained for 6 years. We analysed species richness and composition as a function of time after establishment. We expect the total species number to increase in time, due to the stop of the manure applications and possibilities for the colonisation of not-sown plants. However, we expect the sown species to decrease, because many of them are annuals that probably will not be able to maintain. In the same area, we performed a second study, surveying plant species richness and composition on ditch banks bordered by field margins of different ages. It is expected that the presence of field margins has beneficial effects on species richness on these ditch banks, since they are fenced off from negative influences from the arable fields, like manure and pesticides, and that this effect increases over time.

Our research questions are:

1 Does vascular plant species richness increase in arable field margins sown as habitat for animal species?

2 Does the age of field margins affect species richness of adjacent ditch banks?

The results are used to formulate management recommendations that could improve plant species richness in these agricultural habitats with time.

\section{Field sites and methods}

Field sites

For our first study, we selected 31 arable farms with sown field margins in the province of Zeeland, a marine clay area in the most south-western part of the Netherlands. Of 18 farms, two margins were selected. Not all 49 margins were visited both years: 44 margins in 2006 and 41 margins in 2007 were surveyed, and from 34 margins, data were available from both years. All selected farms had contracts under the AES 'Faunarand' (=fauna margin), and we questioned the farmer on the history of the margins. A contract under this particular scheme lasts for 6 years and prescribes the creation and sowing of a field edge that is at least $6 \mathrm{~m}$ wide and $50 \mathrm{~m}$ long. The seed mixes used by farmers differed and were not always known. As far as we could find out, at least 13 different mixtures were used. Of these, 12 were dominated by herb species, of which again 6 included some grasses. The average number of species was 13.4 (max: 43, min: 2). Table 2 in "Appendix" gives information on the species sown and the frequencies in which the species were encountered in the field. Some farmers implemented this scheme on an already existing margin, but scarification and sowing (and thus the start of vegetation development) was always done at the start of the contract. The age of the margins in our figures therefore starts at ' 1 ' in the year of sowing. Mowing or mulching is permitted once a year between 15th July and 14th September, and regularly done, but the removal of the cuttings is not required, 
and in practice never done. The application of manure or pesticides on the margins is prohibited, but local control of Cirsium arvense and Rumex obtusifolius is allowed.

For the second study, we selected 32 ditch banks in the same region as the first study, all of which were separated from the arable fields by a field margin. All of the locations coincided with the location of our first study. All ditch banks are in all probability constructed in the 1950s. Regional water boards own and manage these ditch banks, generally by mulching once a year.

Vegetation and site characterisation

In week 26-27 of 2006 and 2007, vascular plant species composition on the field margins was recorded in $1 \times 25 \mathrm{~m}$. A recording was positioned in the middle of each margin, never done in margins mowed before within the same year and at least $10 \mathrm{~m}$ from field corners or disturbances such as tire tracks. For our second study, we made in $1 \times 25 \mathrm{~m}$ vegetation recording in week 26-27 of 2006 in the middle of ditch banks which are separated from the arable fields by a field margin. Again, we kept at least $10 \mathrm{~m}$ away from field corners or obvious vegetation disturbances. Plant species occurrence was noted using nomenclature according to van der Meijden (2005), and their abundance was estimated and directed into classes following an adapted BraunBlanquet method (cf. Barkman et al. 1964). In addition, we made a distinction between sown and not-sown species from information supplied by local agri-environmental farmer collectives (see Table 2 in "Appendix"). In the sown mixtures, a number of indigenous plants are included; these were excluded from the 'not-sown plant species richness' analysis, to give the most reliable impression of species richness of colonising plants. Species considered 'sown', but that may also colonise these margins, include Achillea millefolium, Daucus carota, Symphytum officinale, Tanacetum vulgare, Trifolium pratense, Trifolium repens and Tripleurospermum maritimum.

For determining the total nitrogen concentration, soil samples were taken from a depth of $10 \mathrm{~cm}$ at five sites within each plot. The five samples were pooled and thoroughly mixed. Ten gram of fresh weight soil was extracted for $1 \mathrm{~h}$ with $1 \mathrm{M} \mathrm{KCl}$ on a rotary shaker, and water content was determined gravimetrically. Nitrogen content was measured according to Keeney and Nelson (1982).

\section{Analyses}

An explorative principal component analysis (PCA) was performed on all plant species and their logtransformed cover data (in Canoco 4.5). The data were centred by species, not by samples. In order to detect the important clusters of sites based on plant species occurrence, the species and margins shown in the graph are those with a fit higher than $13 \%$ in the analysis.

We used Hierarchical Generalised Linear Models (HGLM), a generalized mixed model procedure of GenStat 12.0, to calculate the relationship between age of the field margin and plant species richness, given the fact that we chose certain farms and years for sampling (Royle and Dorazio 2008). In our models, age of the margin was the main fixed factor. Since we sampled usually two field margins per farm over 2 years, farm, year of sampling, and their interaction were included as random factors. In case of the ditch bank, that we sampled only 1 year, farm was included as random factor. For analysing confounding factors, we included the covariates nitrogen content and width of the field margin, and the factor crop in the field in the fixed part of the model. Plant species richness was log-transformed, $\ln$ (species richness +1 ), to achieve a normal distribution of our response variable. After this transformation, we could use the identity link function both for the fixed and the random part of the model. Age of the field margin was regarded as a categorical variable; nitrogen content was square root transformed to get it close to a normal distribution and crop was in eight categories. The Wald test for testing the change in likelihood between the full model and the reduced model when taking out a variable was used for testing the significance of the fixed variables.

For making the graphs of the relationship between age of the field margin and plant species richness, we applied the complete HGLM's for estimating the mean species richness $( \pm$ s.e.) per age category. In one case, species richness of all species in the field margins where age of the field margin had a significant contribution to the model, we also estimated the regression line of age as scaled variable on 
species richness, again including all other factors in the model. We tested whether the regression coefficient deviated significantly from zero by applying a Wald test again.

For testing whether the age of the field margin affected the nitrogen content of the soil, we again applied a HGLM on square rooted nitrogen content as response variable with the scaled variable age as fixed factor and farm, year of sampling, and their interaction were included as random factors.

\section{Results}

Succession of plant composition in field margins

We recorded 164 vascular plant species in the field margins, of which 68 species are considered to be sown (Table 2 in "Appendix"). The PCA analysis, of which both axes together accounted for $23.4 \%$ of the variation in species composition, showed clear clusters of field margins in relation to their age (Fig. 1). The lower-right part of the graph is dominated by the margins in their first year and the abundant species are many sown species and several ruderal annual species, for example, Chenopodium spp., Persicaria spp. and Solanum nigrum. The upper cluster consists of margins that are 2 years old. Characteristic plants for the margins in this age class are predominately sown biennial or perennial species, for example, Achillea millefolium, Daucus carota, Silene latifolia, etc. The cluster on the lower-left part of the graph represents mostly margins that are 5 and 6 years old. Only a few plant species typify these margins, three grass species, Elytrigia repens, Dactylis glomerata and Poa trivialis, and the nitrophilous species Urtica dioica (Fig. 2). From the sown species, only Centaurea jacea seems well established here.

Succession of plant species richness in field margins

We found the age of the field margin to significantly affect overall species richness (Table 1) and that species richness decreases with age (Wald stat. $=11.889, \mathrm{df}=1$, approx. pr. $=0.001$, Fig. 3). The age of the field margin did not affect species richness of not-sown plants, so the decrease is a result of the decrease of sown plants (Table 1; Fig. 3).
These results were not affected by any of the possible confounding factors, although nitrogen content might had a marginal significant, but unexpectedly positive effect on not-sown species richness (Table 1). No changes in nitrogen content of the soil in relation to the age of the field margin could be found (Wald-stat. $=0.0004, \mathrm{df}=1 ; P=0.983$ ).

Plant species richness on ditch banks bordered by field margins

We recorded 53 vascular plant species in the 32 ditch banks (Table 3 in "Appendix"); only one potentially sown species was recorded: Symphytum officinale. However, this species is highly characteristic for ditch banks and it cannot be excluded that it grows here spontaneously. A PCA analysis did not reveal any apparent clusters (not shown here). In addition, we found no significant effect in plant species richness on ditch banks of the age of the field margin (Table 1). Several grass species (Agrostis stolonifera, Arrhenatherum elatius, Dactylis glomerata and Phragmites australis), including the weed Elytriga repens and Urtica dioica, are the most frequently found species, both in ditch banks next to the recent and next to the older field margins.

\section{Discussion}

Vegetation development

Sown species dominated the recently established field margins. Farmers prefer to sow species in their margins instead of allowing spontaneously colonising vegetation, since they expect weedy annual and rhizomatous species can be prevented this way (van der Meulen et al. 1996; West et al. 1997; Smith et al. 1999). However, the seed mixtures used in Zeeland provide barely protection to both plant groups. Weedy annuals are abundantly found in the margins in their first year; Persicaria and Chenopodium species which have many small seeds that may easily intrude arable fields (de Cauwer et al. 2008). Sequentially, the field margins readily turn into strips with grass species and few herbs (Fig. 2). Both the sown and the annual species do not have many opportunities here and disappear quickly (see also Smith et al. 1999; de Cauwer et al. 2005). The three 
Fig. 1 PCA graph (first two axes) showing the relations between the plant species (arrows and abbreviations) and the field margins, for both only if in the analysis. Plant species are abbreviated by the first five letters of their genus name and the first three letters of their species name. Sown species are underlined. The field margins of different ages are given different symbols: filled triangle margin in the margin in second year, filled square margin in third year, open square margin in fourth year, filled circle margin in fifth year, open square margin in sixth year there is a fit of $13 \%$ or more first year, filled gray square

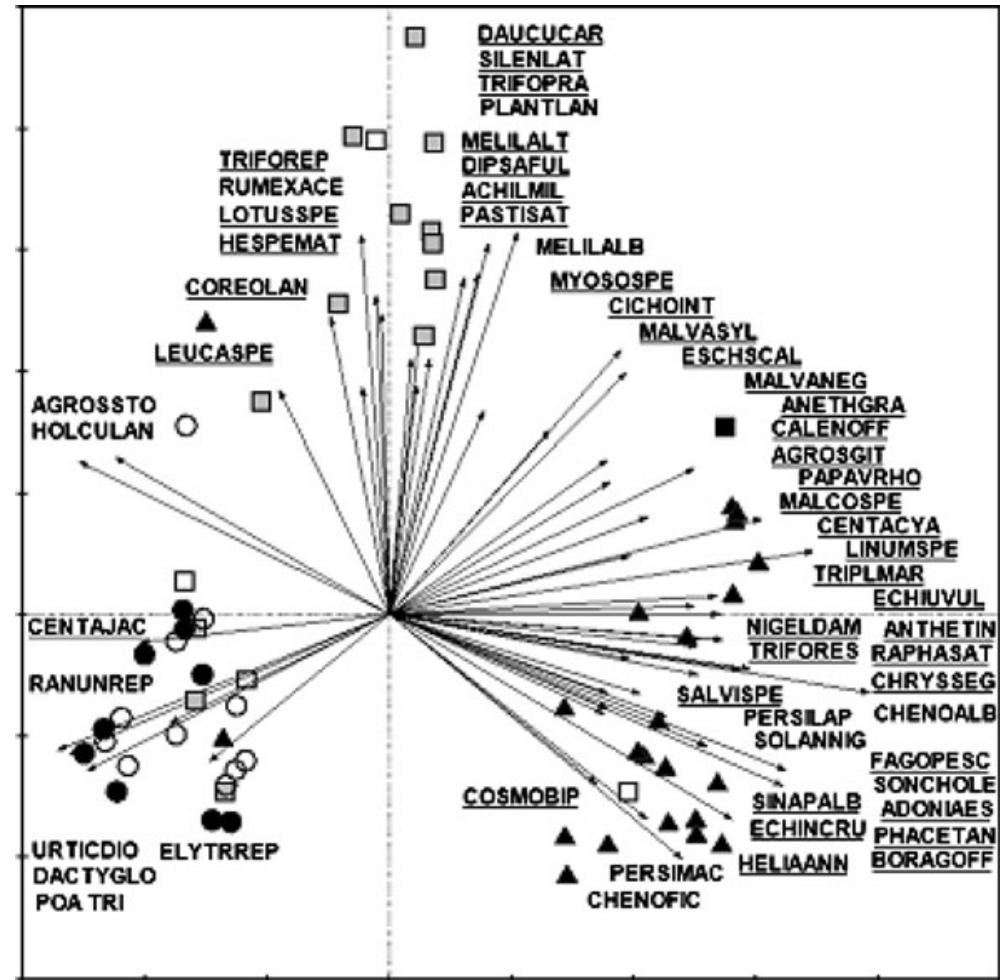

Fig. 2 Example of a field margin in its first year and one after sixth year. Both were sown with a mixture dominated by herbs.

Species composition-and general appearance-has changed dramatically (Photos: B. Kruijsen)
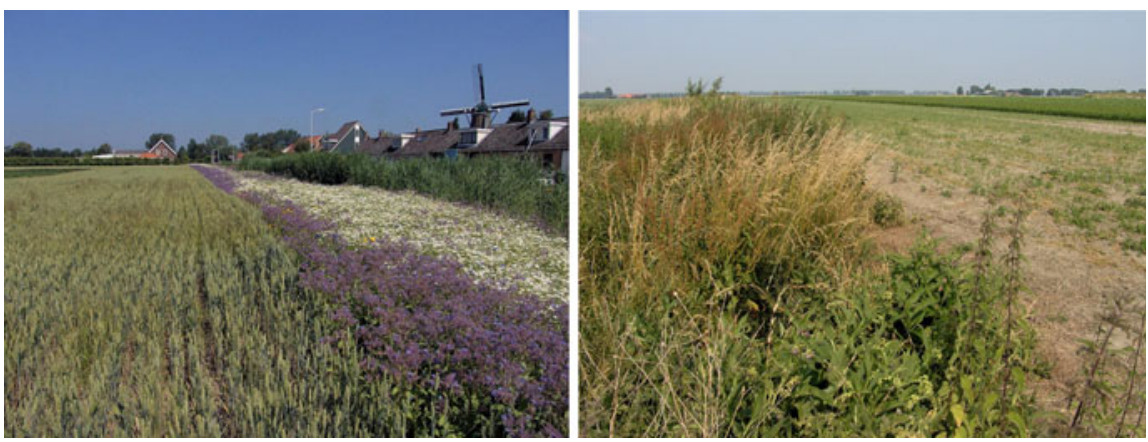

grass species in the cluster representing mainly the old margins (in their fifth and sixth years) are typical for very nutrient-rich situations. A few margins with a younger age can be found in this cluster as well, probably those which have severe nitrogen stress, and the vegetation thus developed quicker into the types with grass dominance. The characteristic and very abundant species in this cluster Elytriga repens and Urtica dioica are considered noxious weeds, because they are rhizomatous (de Cauwer et al. 2008). These species render the margins less accessible to the farmers and roots might spread into the arable field. Most farmers who had such old margins noticed these undesirable effects and some actually stated they would not enter a similar AES again. Generally, the vegetation succession follows the ones described by Hodgson (1989) in the UK and by de Cauwer et al. (2005) in Belgium. It would be relevant to know whether other seed mixtures would result in the same succession. More research is needed here.

Although the composition of the vegetation changes dramatically, the species richness of not-sown species remains stable (see also de Cauwer et al. 2005). Our expectation that in the margins species richness would increase with age could therefore not be affirmed. Old field margins are dominated by few plant species characteristic for very nutrient-rich situations. The nitrogen levels in the field margin soil did not decrease 
Table 1 Results of the complete HGLM

\begin{tabular}{|c|c|c|c|c|}
\hline Fixed term & Sign & Wald stat. & df & Approx. pr. \\
\hline \multicolumn{5}{|c|}{ Field margins: all species } \\
\hline Age & na & 39.04 & 5 & $<0.001$ \\
\hline Nitrogen content & + & 1.09 & 1 & 0.297 \\
\hline Crop in field & na & 5.29 & 7 & 0.625 \\
\hline Width of margin & + & 0.01 & 1 & 0.943 \\
\hline \multicolumn{5}{|c|}{ Field margins: not-sown species } \\
\hline Age & na & 6.22 & 5 & 0.285 \\
\hline Nitrogen content & + & 2.96 & 1 & 0.086 \\
\hline Crop in field & na & 4.40 & 7 & 0.732 \\
\hline Width of margin & + & 1.35 & 1 & 0.246 \\
\hline \multicolumn{5}{|c|}{ Ditch banks: all species } \\
\hline Age & na & 2.261 & 5 & 0.812 \\
\hline Nitrogen content & - & 1.079 & 1 & 0.299 \\
\hline Crop in field & na & 3.190 & 5 & 0.671 \\
\hline Width of margin & - & 0.092 & 1 & 0.761 \\
\hline
\end{tabular}

Species richness of field margins and ditch banks is the response variable. In case of the field margins, farm, year of sampling and their interaction were included as random factors in the models; in case of the ditch banks, farm was included as random factor. Random factors are not presented in the table. Sign correlation coefficient between species richness and factor is positive (+), negative (-) or not applicable (na), $d f$ degrees of freedom, Approx. pr. approximate probability

with the age of the margin. One would expect that margins that are avoided during manure applications would loose nutrients due to leaching from the soil and as a consequence decrease in fertility. However, in the clay soils of our study area, leaching is probably very slow or even absent. And since mowing of the margins does not include the removal of plant material here, nutrients stay available in the field margins.

Although some studies show short-term positive effects of adjacent field margins on plant species richness of the ditch banks, due to the fencing off from pollution and disturbances from the arable fields (e.g., Kleijn and Snoeijing 1997; de Snoo and van der Poll 1999; Musters et al. 2009), the banks studied in Zeeland did not develop into more species-rich sites within the studied 6 years. This is probably due the mulching management, which also does not include removal of plant material, resulting in remaining nutrient availability. In all the cases studied by Muster et al. (2009), plant removal took place.

In conclusion, these field margins initially created for fauna, offer poor opportunities for plant species richness conservation, probably due to a management
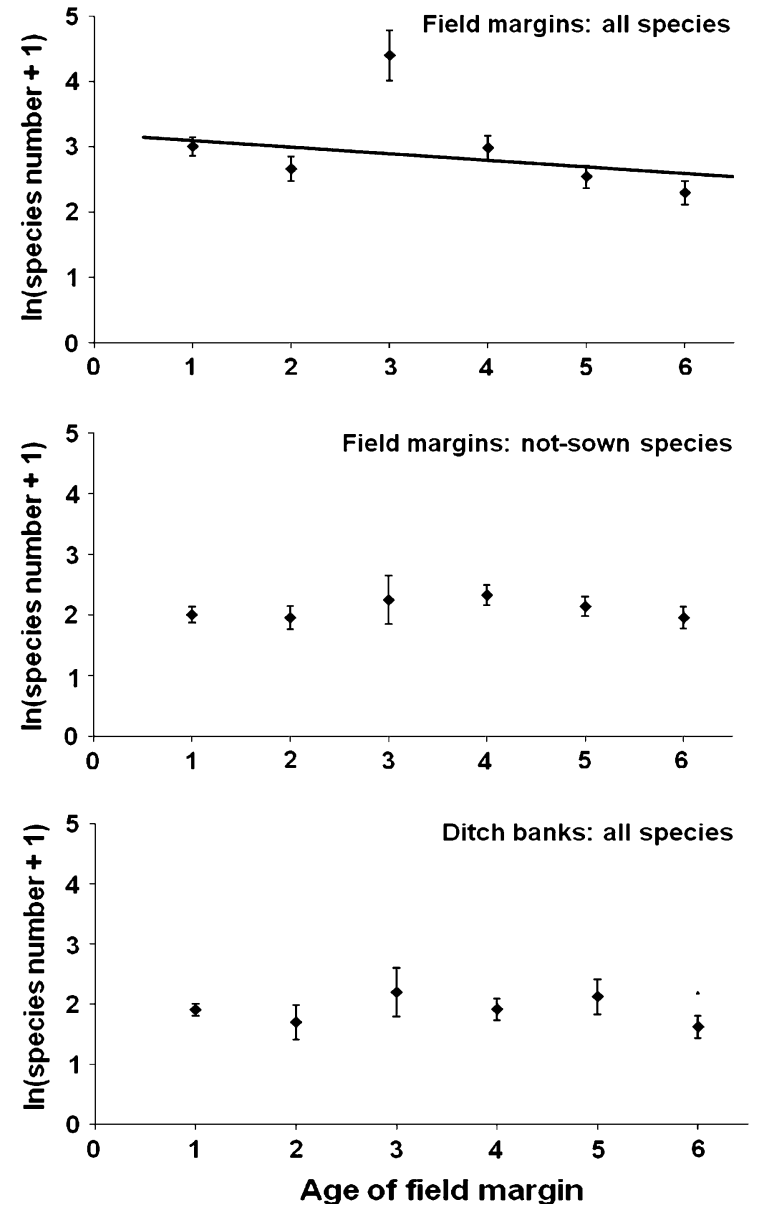

Fig. 3 Estimated mean diversity ( \pm s.e.) and linear regression of all and not-sown plant species in relation to the age of field margin, based on HGLM (Table 1). Age 1 reflects the first growing season after the margins were sown in winter. The decrease in species richness of all species in field margins is significantly different from zero $(P<0.001)$

inappropriate for this group. An alternative explanation could be that the sown seed mixture is inappropriate.

\section{Management recommendations}

In order to obtain higher plant species richness on field margins and ditch banks, several management and landscape characteristics are important, such as a reduction of fertilizer inputs from the fields (Kleijn and Verbeek 2002) and the presence of nearby species-rich areas (Kohler et al. 2008; Leng et al. 2009). However, from our study it is clear that an increase in plant species richness may be hampered 
by the current management, both in the field margins as on the ditch banks. In the two linear elements, the lack of biomass removal may hamper a reduction of nutrients. Besides, litter accumulation may hinder the colonisation or growth of many plant species. Pinpointing appropriate management therefore seems a very important first step towards biodiversity gain in these habitats (Manhoudt et al. 2007). The implementation of a hay-making management (mowing with the sequential removal of the cutting) seems most urgent to enhance plant species richness. Various researches recommend this as well for such nutrient-enriched field margins, for example, Marshall and Nowakowski (1995), Smith et al. (1999), de Cauwer et al. (2005), Hovd and Skogen (2005) and Manhoudt et al. (2007). In addition, to avoid nutrient leaching from the mown vegetation, the quick removal of the cuttings is necessary (Schaffers et al. 1998). Not only is biomass removal associated with nutrient removal, it also prevents litter accumulation (Schaffers 2002). Dense litter and vegetation layers affect seed germination and seedling establishment (Schaffers 2002). Thus, the creation of open situations, either by hay-making or by locally opening up the vegetation, i.e. by creating gaps of bare ground, may offer opportunities for botanically diverse vegetation (Schaffers 2002; Blomqvist et al. 2006).

Farmers probably welcome a different management prescription of the AES, since a hay-making and opening management fits their perception of well-maintained fields and would result in fewer noxious weeds. However, this management requires extra costs to be made.

Acknowledgements We are indebted to E. Gertenaar for assistance during fieldwork and to A.M. Lokhorst and H. Staats for input in the study design. In addition, we would like to thank all representatives of participating farmer collectives and all individual farmers for their efforts in contributing in this research and allowing us to perform the field inventories. A.P. Schaffers and Th. Heijerman assisted in the making of the graphs. This study was financially supported by the Netherlands Organization for Scientific Research (NWO), grant number 474-03-385.

Open Access This article is distributed under the terms of the Creative Commons Attribution Noncommercial License which permits any noncommercial use, distribution, and reproduction in any medium, provided the original author(s) and source are credited.

\section{Appendix}

See Tables 2 and 3.

Table 2 All recorded plant species in the field margins

\begin{tabular}{|c|c|}
\hline Species & Percentage of margins \\
\hline Achillea millefolium & 20.5 \\
\hline Adonis aestivalis & 6.0 \\
\hline$\underline{\text { Agrostemma githago }}$ & 7.2 \\
\hline Agrostis stolonifera & 38.6 \\
\hline Alopecurus pratensis & 4.8 \\
\hline Ambrosia spec. & 1.2 \\
\hline Anagallis arvensis s. arvensis & 1.2 \\
\hline Anethum graveolens & 20.5 \\
\hline Angelica archangelica & 1.2 \\
\hline Anisantha sterilis & 2.4 \\
\hline Anthemis tinctoria & 13.3 \\
\hline Anthriscus sylvestris & 12.1 \\
\hline Apera spica-venti & 4.8 \\
\hline Arrhenatherum elatius & 16.9 \\
\hline Artemisia vulgaris & 4.8 \\
\hline Atriplex littoralis & 2.4 \\
\hline Atriplex patula & 1.2 \\
\hline Atriplex prostrate & 1.2 \\
\hline$\underline{\text { Avena sativa }}$ & 6.0 \\
\hline Bellis perennis & 1.2 \\
\hline$\underline{\text { Beta }}$ spec. & 3.6 \\
\hline Bolboschoenus maritimus & 1.2 \\
\hline Borago officinalis & 30.1 \\
\hline$\underline{\text { Brassica napus }}$ & 9.6 \\
\hline$\underline{\text { Brassica nigra }}$ & 1.2 \\
\hline$\underline{\text { Brassica rapa }}$ & 1.2 \\
\hline Calendula officinalis & 16.9 \\
\hline Calystegia sepium & 13.3 \\
\hline Capsella bursa-pastoris & 7.2 \\
\hline Carex otrubae & 1.2 \\
\hline Carum carvi & 1.2 \\
\hline Carum spec. & 2.4 \\
\hline Centaurea cyanus & 31.3 \\
\hline Centaurea jacea & 24.1 \\
\hline Chenopodium album & 28.9 \\
\hline Chenopodium ficifolium & 20.5 \\
\hline Chenopodium polyspermum & 6.0 \\
\hline Chenopodium rubrum & 3.6 \\
\hline
\end{tabular}


Table 2 continued

\begin{tabular}{|c|c|}
\hline Species & Percentage of margins \\
\hline Chrysanthemum segetum & 13.3 \\
\hline Cichorium intybus & 10.8 \\
\hline Cirsium arvense & 36.1 \\
\hline Cirsium vulgare & 14.5 \\
\hline Consolida regalis & 1.2 \\
\hline Convolvulus arvensis & 8.4 \\
\hline Conyza canadensis & 1.2 \\
\hline Coreopsis lanceolata & 3.6 \\
\hline Coronopus squamatus & 1.2 \\
\hline Cosmos bipinnatus & 7.2 \\
\hline Crataegus monogyna & 3.6 \\
\hline Crepis capillaries & 4.8 \\
\hline Cynoglossum amabile & 1.2 \\
\hline Cynosurus cristatus & 1.2 \\
\hline Dactylis glomerata & 39.8 \\
\hline Daucus carota & 26.5 \\
\hline Dipsacus fullonum & 6.0 \\
\hline Echinochloa crus-galli & 12.1 \\
\hline Echium vulgare & 12.1 \\
\hline Elytrigia repens & 54.2 \\
\hline Epilobium hirsutum & 13.3 \\
\hline Epilobium parviflorum & 2.4 \\
\hline Epilobium tetragonum & 2.4 \\
\hline Equisetum arvense & 21.7 \\
\hline Eschscholzia californica & 6.0 \\
\hline Euphorbia helioscopia & 6.0 \\
\hline Fagopyrum esculentum & 13.3 \\
\hline Fallopia convolvulus & 2.4 \\
\hline Festuca arundinacea & 12.1 \\
\hline Festuca cinerea & 3.6 \\
\hline Festuca pratensis & 3.6 \\
\hline Festuca rubra & 1.2 \\
\hline Galium aparine & 10.8 \\
\hline Galium mollugo & 4.8 \\
\hline Geranium dissectum & 10.8 \\
\hline Geranium molle & 6.0 \\
\hline Glechoma hederacea & 6.0 \\
\hline Gypsophila muralis & 1.2 \\
\hline Helianthus annuus & 18.1 \\
\hline Hesperis matronalis & 12.1 \\
\hline Holcus lanatus & 30.1 \\
\hline Hordeum vulgare & 6.0 \\
\hline Lactuca serriola & 13.3 \\
\hline Lamium purpureum & 8.4 \\
\hline
\end{tabular}

Table 2 continued

\begin{tabular}{|c|c|}
\hline Species & Percentage of margins \\
\hline Lapsana communis & 4.8 \\
\hline Lepidium sativum & 2.4 \\
\hline Leucanthemum spec. & 27.7 \\
\hline Linaria $\underline{\text { spec. }}$ & 2.4 \\
\hline Linum spec. & 9.6 \\
\hline Lolium perenne & 25.3 \\
\hline Lotus spec. & 20.5 \\
\hline$\underline{\text { Malcolmia spec. }}$ & 4.8 \\
\hline Malva moschata & 1.2 \\
\hline Malva neglecta & 6.0 \\
\hline Malva sylvestris & 44.6 \\
\hline Matricaria recutita & 13.3 \\
\hline Medicago lupulina & 8.4 \\
\hline Medicago sativa & 22.9 \\
\hline Melilotus albus & 4.8 \\
\hline Melilotus altissimus & 7.2 \\
\hline Myosotis spec. & 9.6 \\
\hline Nigella damascene & 9.6 \\
\hline Oenothera erythrosepala & 6.0 \\
\hline Papaver rhoeas & 22.9 \\
\hline Papaver somniferum & 1.2 \\
\hline$\underline{\text { Pastinaca sativa }}$ & 7.2 \\
\hline Persicaria amphibia & 3.6 \\
\hline Persicaria lapathifolia & 13.3 \\
\hline Persicaria maculosa & 19.3 \\
\hline Phacelia tanacetifolia & 37.4 \\
\hline Phalaris arundinacea & 1.2 \\
\hline Phalaris canariensis & 1.2 \\
\hline Phleum pratense s. pratense & 6.0 \\
\hline Phragmites australis & 10.8 \\
\hline Plantago lanceolata & 19.3 \\
\hline Plantago major s. major & 14.5 \\
\hline Роа аппиа & 2.4 \\
\hline Poa pratensis & 3.6 \\
\hline Poa trivialis & 25.3 \\
\hline Polygonum aviculare & 12.1 \\
\hline Populus spec. & 2.4 \\
\hline Pulicaria dysenterica & 1.2 \\
\hline Ranunculus repens & 15.7 \\
\hline$\underline{\text { Raphanus sativus }}$ & 26.5 \\
\hline Reseda spec. & 1.2 \\
\hline Ribes spec. & 1.2 \\
\hline Rubus fruticosus ag. & 8.4 \\
\hline Rumex acetosa & 4.8 \\
\hline
\end{tabular}


Table 2 continued

\begin{tabular}{|c|c|}
\hline Species & Percentage of margins \\
\hline Rumex conglomeratus & 4.8 \\
\hline Rumex crispus & 18.1 \\
\hline Rumex obtusifolius & 19.3 \\
\hline Rumex sanguineus & 1.2 \\
\hline$\underline{\text { Salvia }}$ spec. & 6.0 \\
\hline Sambucus nigra & 2.4 \\
\hline$\underline{\text { Securigera varia }}$ & 2.4 \\
\hline Senecio jacobaea & 8.4 \\
\hline Setaria spec. & 3.6 \\
\hline Silene armeria & 1.2 \\
\hline Silene dioica & 1.2 \\
\hline Silene latifolia & 28.9 \\
\hline Silene vulgaris & 1.2 \\
\hline Sinapis alba & 19.3 \\
\hline Sinapis arvensis & 2.4 \\
\hline Solanum nigrum s. nigrum & 8.4 \\
\hline Solanum tuberosum & 3.6 \\
\hline Sonchus arvensis & 20.5 \\
\hline Sonchus asper & 20.5 \\
\hline Sonchus oleraceus & 16.9 \\
\hline Symphytum officinale & 7.2 \\
\hline$\underline{\text { Tanacetum parthenium }}$ & 6.0 \\
\hline$\underline{\text { Tanacetum vulgare }}$ & 7.2 \\
\hline Taraxacum spec. & 18.1 \\
\hline Thlaspi arvense & 6.0 \\
\hline Trifolium pratense & 31.3 \\
\hline$\underline{\text { Trifolium repens }}$ & 12.1 \\
\hline$\underline{\text { Trifolium resupinatum }}$ & 15.7 \\
\hline$\underline{\text { Trifolium }}$ spec. & 3.6 \\
\hline$\underline{\text { Tripleurospermum maritimum }}$ & 31.3 \\
\hline Triticum aestivum & 13.3 \\
\hline Tussilago farfara & 3.6 \\
\hline Urtica dioica & 37.4 \\
\hline Veronica persica & 7.2 \\
\hline Vicia sativa & 4.8 \\
\hline$\underline{\text { Vicia }}$ spec. & 6.0 \\
\hline Viola tricolor & 2.4 \\
\hline Vulpia spec. & 1.2 \\
\hline
\end{tabular}

Species indicated with spec. are distinctly different from other species of the same genus and are therefore regarded as separate species in all analyses. The species appearing in seed mixtures are given underlined. To provide an indication of the occurrence of the species, the percentage of the total number of studied field margins where each of it was recorded is given. The nomenclature follows the programme TURBOVEG (see Hennekens and Schaminée 2001)
Table 3 All recorded plant species on the ditch banks

\begin{tabular}{|c|c|}
\hline Species & Percentage of ditch banks \\
\hline Agrostis stolonifera & 39.4 \\
\hline Anthriscus sylvestris & 24.2 \\
\hline Arrhenatherum elatius & 42.4 \\
\hline Atriplex prostrata & 3.0 \\
\hline Betula pendula & 6.1 \\
\hline Bolboschoenus maritimus & 3.0 \\
\hline Calystegia sepium & 15.2 \\
\hline Carex otrubae & 6.1 \\
\hline Cirsium arvense & 6.1 \\
\hline Convolvulus arvensis & 3.0 \\
\hline Crepis capillaris & 3.0 \\
\hline Dactylis glomerata & 48.5 \\
\hline Elytrigia repens & 66.7 \\
\hline Epilobium hirsutum & 6.1 \\
\hline Epilobium parviflorum & 3.0 \\
\hline Epilobium tetragonum & 3.0 \\
\hline Equisetum arvense & 27.3 \\
\hline Fallopia convolvulus & 3.0 \\
\hline Festuca arundinacea & 21.2 \\
\hline Festuca cinerea & 6.1 \\
\hline Festuca pratensis & 3.0 \\
\hline Festuca rubra & 3.0 \\
\hline Galium aparine & 3.0 \\
\hline Glechoma hederacea & 3.0 \\
\hline Hieracium aurantiacum & 3.0 \\
\hline Holcus lanatus & 6.1 \\
\hline Lolium perenne & 6.1 \\
\hline Lotus corniculatus & 3.0 \\
\hline Persicaria amphibia & 3.0 \\
\hline Phleum pratense s. pratense & 3.0 \\
\hline Phragmites australis & 51.5 \\
\hline Plantago lanceolata & 6.1 \\
\hline Poa pratensis & 3.0 \\
\hline Poa trivialis & 9.1 \\
\hline Ranunculus repens & 3.0 \\
\hline Rubus caesius & 3.0 \\
\hline Rubus fruticosus ag. & 21.2 \\
\hline Rumex conglomeratus & 3.0 \\
\hline Rumex sanguineus & 3.0 \\
\hline Rumex species & 3.0 \\
\hline Salicornia species & 3.0 \\
\hline Salix alba & 3.0 \\
\hline Salix daphnoides & 3.0 \\
\hline Sambucus nigra & 3.0 \\
\hline
\end{tabular}


Table 3 continued

\begin{tabular}{lc}
\hline Species & Percentage of ditch banks \\
\hline Schoenoplectus lacustris & 3.0 \\
Senecio jacobaea s. jacobaea & 6.1 \\
Sonchus arvensis & 3.0 \\
Sonchus asper & 6.1 \\
Sonchus oleraceus & 9.1 \\
Symphytum officinale & 3.0 \\
Taraxacum species & 6.1 \\
Tussilago farfara & 3.0 \\
Urtica dioica & 39.4
\end{tabular}

To provide an indication of the occurrence of the species, the percentage of the total number of ditch banks where each species was recorded is given. The nomenclature follows the programme TURBOVEG (see Hennekens and Schaminée 2001)

\section{References}

Asteraki EJ, Hart BJ, Ings TC, Manley WJ (2004) Factors influencing the plant and invertebrate diversity of arable field margins. Agric Ecosyst Environ 202:219-231

Barkman JJ, Doing H, Segal S (1964) Kritische Bemerkungen und Vorschläge zur quantitativen Vegetationsanalyse. Acta Bot Neerlandica 13:394-419

Blomqvist MM, Tamis WLM, Bakker JP, van der Meijden E (2006) Seed and (micro)site limitation in ditch banks: germination, establishment and survival under different management regimes. J Nat Conserv 14:16-33

Blomqvist MM, Tamis WLM, de Snoo GR (2009) No improvement of plant biodiversity in ditch banks after a decade of agri-environment schemes. Basic Appl Ecol 10:368-378

de Cauwer B, Reheul D, D'hooghe K, Nijs I, Milbau A (2005) Evolution of the vegetation of mown field margins over their first 3 years. Agric Ecosyst Environ 109:87-96

de Cauwer B, Reheul D, Nijs I, Milbau A (2008) Management of newly established field margins on nutrient-rich soil to reduce weed spread and seed rain into adjacent crops. Weed Res 48:102-112

de Snoo GR (1999) Unsprayed field margins: effects on environment, biodiversity and agricultural practice. Landsc Urban Plan 46:151-160

de Snoo GR, de Wit PJ (1998) Buffer zones for reducing pesticide drift to ditches and risks to aquatic organisms. Ecotoxicol Environ Saf 41:112-118

de Snoo GR, van der Poll RJ (1999) Effect of herbicide drift on adjacent boundary vegetation. Agric Ecosyst Environ $73: 1-6$

Hennekens SM, Schaminée JHJ (2001) Turboveg, a comprehensive database management system for vegetation data. J Veg Sci 12:589-591

Hodgson JG (1989) Selecting and managing plant materials used in habitat construction. In: Buckley GP (ed)
Biological habitat reconstruction. Belhaven Press, London, pp 45-67

Hovd H, Skogen A (2005) Plant species in arable field margins and road verges of central Norway. Agric Ecosyst Environ 110:257-265

Keeney DR, Nelson DW (1982) Nitrogen-inorganic forms. In: Page AL, Miller RH, Keeney DR (eds) Methods of soil analysis: Part 2, 2nd edn. Agronomy monographs, vol 9. ASA and SSSA, Madison, WI, pp 643-687

Kiss J, Penksza K, Tóth F, Kádár F (1997) Evaluation of fields and field margins in nature production capacity with special regard to plant protection. Agric Ecosyst Environ 63:227-232

Kleijn D, Snoeijing GIJ (1997) Field boundary vegetation and the effects of drift of agrochemicals: botanical change caused by low levels of herbicide and fertilizer. J Appl Ecol 34:1413-1425

Kleijn D, Sutherland WJ (2003) How effective are European agri-environment schemes on conserving and promoting biodiversity? J Appl Ecol 40:947-970

Kleijn D, Verbeek M (2002) Factors affecting the species composition of arable field boundary vegetation. J Appl Ecol 37:256-266

Kleijn D, Baquero RA, Clough Y, Díaz M, De Esteban J, Fernández F, Gabriel D, Herzog F, Holzschuh A, Jöhl R, Knop E, Kruess A, Marshall EJP, Steffan-Dewenter I, Tscharntke T, Verhulst J, West TM, Yela JL (2006) Mixed biodiversity benefits of agri-environment schemes in five European countries. Ecol Lett 9:243-254

Kohler F, Verhulst J, Van Klink R, Kleijn D (2008) At what spatial scale do high-quality habitats enhance the diversity of forbs and pollinators in intensively farmed landscapes? J Appl Ecol 45:753-762

Leng X, Musters CJM, de Snoo GR (2009) Restoration of plant diversity on ditch banks: seed and site limitation in response to agri-environment schemes. Biol Conserv 142:1340-1349

Manhoudt AGE, de Snoo GR (2003) A quantitative survey of seminatural habitats on Dutch arable farms. Agric Ecosyst Environ 97:235-240

Manhoudt AGE, Visser AJ, de Snoo GR (2007) Management regimes and farming practices enhancing plant species richness on ditch banks. Agric Ecosyst Environ 119:353358

Marshall EJP, Moonen AC (2002) Field margins in northern Europe: their functions and interactions with agriculture. Agric Ecosyst Environ 89:5-21

Marshall EJP, Nowakowski M (1995) Successional changes in flora of a sown field margin strip managed by cutting and herbicide application. Brighton crop protection conference-weeds. The British Crop Protection Council, Farnham, Surrey, pp 973-978

Moonen AC, Marshall EJP (2001) The influence of sown margin strips, management and boundary structure on herbaceous field margin vegetation in two neighbouring farms in southern England. Agric Ecosyst Environ 86:187-202

Musters CJM, van Alebeek F, Geers RHEM, Korevaar H, Visser A, de Snoo GR (2009) Development of biodiversity in field margins recently taken out of production and 
adjacent ditch banks in arable areas. Agric Ecosyst Environ 129:131-139

Royle JA, Dorazio RM (2008) Hierarchical modelling and inference in ecology. Academic Press, London

Schaffers AP (2002) Soil, biomass, and management of seminatural vegetation. II. Factors controlling species diversity. Plant Ecol 158:247-268

Schaffers AP, Vesseur MC, Sýkora KV (1998) Effects of delayed hay removal on the nutrient balance in roadside vegetation. J Appl Ecol 35:349-364

Schaffers AP, Raemakers IP, Sýkora KV, ter Braak CJF (2008) Arthropod assemblages are best predicted by plant species composition. Ecology 89:782-794

Smith H, Firbank LG, Macdonald DW (1999) Uncropped edges of arable field managed for biodiversity do not increase weed occurrence in adjacent crops. Biol Conserv 89:107-111 van der Meijden, R (2005) Heukels' flora van Nederland, 23ste druk. Wolters-Noordhoff, Groningen

van der Meulen HAB, de Snoo GR, Wossink GAA (1996) Farmers' perception of unsprayed crop edges in the Netherlands. J Environ Manag 47:241-255

Walker KJ, Critchley CNR, Sherwood AJ, Large R, Nuttall P, Hulmes S, Rose R, Mountford JO (2007) The conservation of arable plants on cereal field margins: an assessment of new agri-environment scheme options in England, UK. Biol Conserv 136:260-270

West TM, Marshall EJP, Arnold GM (1997) Can sown field boundary strips reduce the ingress of aggressive field margin weeds? Brighton crop protection conference-weeds. British Crop Protection Council, Farnham, pp 985-990

Whittingham MJ (2007) Will agri-environment schemes deliver substantial biodiversity gain, and if not why not? J Appl Ecol 44:1-5 